\title{
滴状凝縮サーモサイフォンの熱輸送特性に関する理論的検討*
}

\section{Theoretical Study on Heat Transfer Characteristics of Dropwise Condensed Thermosyphon}

\author{
Hiroyuki SHIRAIWA*1
} ${ }^{* 1}$ Miyakonojo National College of Technology, Dept. of Mechanical Engineering
Yoshio-cho 473-1, Miyakonojo-shi, Miyazaki, 885-8567 Japan

In recent years, there has been a demand for the development of a high-efficient heat exchanger for the purpose of saving energy and resources. A two-phase closed thermosyphon is a heat exchanging device which operates with no external power in a closed system and transports a large heat amount with a very small temperature difference between the ends of the pipe. Therefore, a thermosyphon is extremely effective at solving energy and environmental problems. In this study, the heat transfer characteristics of the dropwise condensed thermosyphon and the influence of condensation forms on the heat transfer characteristics is theoretically investigated. As a result, the change ratio of the heat transfer characteristics of the thermosyphon by the difference of the condensation form was able to be estimated by this proposed theoretical calculation method.

Key Words : Thermosyphon, Dropwise Condensation, Heat Transfer Characteristic, Theoretical Analysis

\section{1. 緒言}

近年，環境問題に関連して，省エネルギー，省資源も重要な問題として取り上げられており，将来において自 然エネルギーの利用，あるいは工場からの排熱などの有効利用を図ることが重要なエネルギ一対策として考えら れる，そこで，さまざまなエネルギーの有効利用を目的とした高性能，高効率の熱交換器の開発が強く望まれて いる. このような熱交換器の一種であるヒートパイプ (1) (2) は, 外部動力を必要とせず, 閉じた系の中で作動, 運転でき，わずかな熱源の温度差で比較的多量の熱輸送を行うことのできる熱輸送デバイスとして注目されてい る. このヒートパイプの一形式である二相・密閉型サーモサイフォン ${ }^{(3)} \sim{ }^{(6)}$ （以下，「サーモサイフォン」と称 する. ）は，凝縮液の還流に重力の作用を用いるのが特徵である．その原理は極めて簡単であり，高性能熱輸送デ バイスとして知られている. そのため, サーモサイフォンは多方面において広く実用化されている. その一方で, サーモサイフォン内部の流れと熱輸送現象に関しては，相変化を伴う蒸発および凝縮現象が混在し，その流動状 態についても複雑であるため, 蒸発部, 断熱部, 凝縮部の各構成部間のシステムとしての解析は確立していない. また，凝縮部における凝縮形態は，一般的な表面式熱交換において広く実用化されている膜状凝縮を対象とした 調査，研究のみが行われてきており，膜状凝縮よりも大きな熱伝達率を有する滴状凝縮についての検討はほとん ど見られない.

そこで，著者らは，サーモサイフォンの熱輸送特性（主に熱輸送量，熱抵抗を指す．以下同じ.）に及ぼす凝縮形 態の影響について実験的に検討を行ってきた ${ }^{(7)}$. その結果, 膜状凝縮の場合よりも滴状凝縮の場合に優れた熱輸送 特性を示し，熱輸送量の増加率は約 40～60\%であることがわかった。しかしながら，限られた状況下での実験であ り，今後の各種伝熱機器等への滴状凝縮の応用を考えた場合，膜状凝縮を滴状凝縮に変更することによる伝熱促進 割合を概算的に評価する簡易手法の確立が強く望まれる，なお，以下，サ一モサイフォン凝縮部に膜状凝縮を適用 した場合を「膜状凝縮サーモサイフォン」, 滴状凝縮を適用した場合を「滴状凝縮サーモサイフォン」と称する. 本研究では, サーモサイフォンの熱輸送特性に及ぼす凝縮形態の影響について理論的に検討を行う.すなわち,

\footnotetext{
* 原稿受付 2011 年 3 月 10 日

*1 正員, 都城工業高等専門学校（广885-8567 宮崎県都城市吉尾町 473-1）

E-mail: shiraiwa@cc.miyakonojo-nct.ac.jp
} 
滴状凝縮の熱伝達理論として Le Fevre-Rose の理論 ${ }^{(8)}$ を用い，膜状凝縮サーモサイフォンのシステム解析理論で ある大島の理論 ${ }^{(9)}$ と組み合わせることにより, 滴状凝縮サーモサイフォンの熱輸送特性を理論的に求める. そし て, 従来の膜状凝縮サーモサイフォンの熱輸送特性に関する大島の理論值，および実験值と比較，検討を行う．

\section{2. 滴状凝縮の熱伝達理論}

温度の不均一や変動のない静止した鉛直凝縮面上における，不凝縮ガスを含まない蒸気の滴状凝縮熱伝達に関 する Le Fevre-Rose $の$ 理論 ${ }^{(8)}$ について, 概略を下記する. なお, 以下の計算において, 液滴の形状は半球欠と仮 定している.

\section{$2 \cdot 1$ 一個の液滴における熱伝達の理論解析}

一個の液滴に関して, 液滴の底面を通って凝縮面に向かう熱流束 $q_{B}$ と凝縮面過冷度 $\Delta T_{C}\left(=T_{S}-T_{C}, T_{S}\right.$ : 飽和蒸 気温度, $T_{C}$ : 凝縮面温度）の関係は式（1）で表される.

$$
q_{B}=\frac{\frac{\Delta T_{C}}{T_{S}}-\frac{2 \sigma v_{l}}{r \Gamma}}{\frac{K_{1} r}{\lambda T_{S}}+\frac{K_{2}}{q_{2}}}
$$

ここで, $r$ は液滴半径, $\sigma$ は凝縮液の表面張力, $v_{l}$ は凝縮液の比体積, $v_{v}$ は蒸気の比体積, $\Gamma$ は潜熱, $\lambda$ は凝縮液 の熱伝導率, $\kappa$ は比熱比, $R$ はガス定数であり， $q_{2}$ は式（2）で表される.

$$
q_{2}=\frac{\Gamma^{2}}{v_{v}} \sqrt{\frac{2 \pi}{R T_{S}}} \frac{\kappa-1}{\kappa+1}
$$

また， $K_{1}$ は液滴中での温度降下 $\Delta T_{d}$ と $q_{B}$ を関係づける定数であり，式（3）で定義される.

$$
q_{B}=\frac{\lambda}{K_{1} r} \Delta T_{d}
$$

式 (3) では, 半径 $r$ の液滴を等価的な厚み $K_{1} r$ に置き換えることを意味しており, 液滴を同一体積の直円柱と仮 定した場合, 直円柱の高さは $2 r / 3$ となることから, $K_{1}=2 / 3$ となる. さらに, $K_{2}$ は液滴底面と液滴表面との面積比 および滴状凝縮の促進剤層の熱抵抗に関連寸る係数であり, 促進剤の種類によって表 $1^{(10)}$ のようになることが 知られている.

Table 1 Relationship between promoter of dropwise condensation and $K_{2}{ }^{(10)}$

\begin{tabular}{|c|c|}
\hline Promoter of dropwise condensation & $K_{2}$ \\
\hline \hline Dioctadecyl disulphide & 1.046 \\
\hline Primary amine & 1.065 \\
\hline Dodecane silane & 2.255 \\
\hline Montan wax & 1.162 \\
\hline Dioctadecyl disulphide & 0.937 \\
\hline Montanic acid & 0.502 \\
\hline Dibenzil disulphide & 2.122 \\
\hline Oleic acid & 2.155 \\
\hline
\end{tabular}




\section{$2 \cdot 2$ 凝縮面上の液滴の大きさの分布を考慮した場合の熱伝達の理論解析}

液滴の大きさの分布について考える. 凝縮面のうち, 半径が $r$ から $r_{\max }$ （最大（または離脱）液滴半径）まで の液滴で覆われている面積割合を $\alpha$ とすると， $\alpha$ は式 (4) で表される.

$$
\alpha=1-\left(\frac{r}{r_{\max }}\right)^{1 / n}
$$

ここで, $n$ は定数であり, 理論的に $n \geqq 1.4$ となる. また, 最大（または離脱）液滴半径 $r_{\max }$ は, 液滴を半球欠と 仮定した場合, 理論的に $r_{\max }=1.1 \times 10^{-3} \mathrm{~m}$ となる ${ }^{(11)}$.

以上より，一個の液滴に関する熱流束の関係式（1）を用い，凝縮面上の液滴の大きさの分布を考慮した場合の 凝縮面全体における平均熱流束 $q_{C}$ は式（5）となる.

$$
q_{C}=\int_{r_{\min }}^{r_{\max }} \frac{\frac{\Delta T_{C}}{T_{S}}-\frac{2 \sigma v_{l}}{r \Gamma}}{\frac{K_{1} r}{\lambda T_{S}}+\frac{K_{2}}{q_{2}}}\left[\frac{1}{n}\left(\frac{r}{r_{\max }}\right)^{(1-n) / n}\right] \frac{d r}{r_{\max }}
$$

ここで， $r_{\min }$ は最小液滴半径であり, 理論的に式（6）で表される.

$$
r_{\min }=\frac{2 \sigma v_{l}}{\Gamma} \frac{T_{S}}{\Delta T_{C}}
$$

\section{3. 滴状凝縮サ一モサイフォンの熱輸送特性に関するシステム解析理論}

図 1 に示寸ような円形の滴状凝縮サーモサイフォンについて, 蒸発部, 断熱部, 凝縮部間の熱エネルギーの移 動をシステム的に解析する理論的手法について, 以下, 詳述する. なお, サーモサイフォン内には, 空気等の不 凝縮ガスは存在しないものとする.

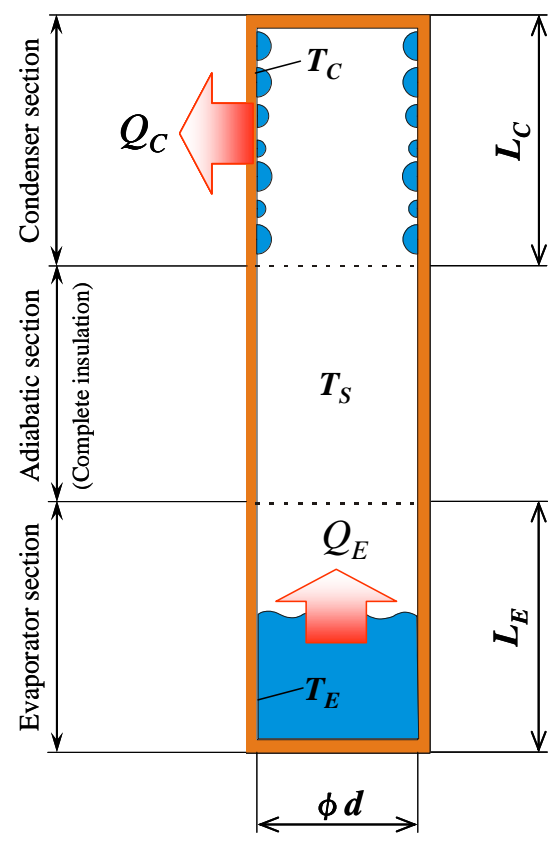

$$
\begin{array}{|ll}
\hline Q_{E} & : \text { heat transfer rate of evaporator section } \\
Q_{C} & : \text { heat transfer rate of condenser section } \\
T_{E} & : \text { temperature of heating surface } \\
T_{C} & : \text { temperature of condensing surface } \\
T_{S} & : \text { temperature of saturated vapor } \\
L_{E} & : \text { length of evaporator section } \\
L_{C} & : \text { length of condenser section } \\
d & : \text { inlet diameter of thermosyphon }
\end{array}
$$

Fig. 1 Calculation model for dropwise condensed thermosyphon 


\section{$3 \cdot 1$ 膜状凝縮サ一モサイフォンに関する大島の理論}

大島は円形の膜状凝縮サーモサイフォンの蒸発部と凝縮部の伝熱量の釣り合いから，蒸発部と凝縮部の温度差 (熱源温度差) $\Delta T_{E C}\left(=T_{E}-T_{C}, T_{E}\right.$ : 加熱面温度） と熱輸送量 $Q_{F}$ の関係を理論的に導いている ${ }^{(9)}$.

この大島の理論では, 蒸発部での作動液の蒸発状態を加熱面に気泡が発生しない表面蒸発と仮定し，蒸発部の 伝熱量 $Q_{E}$ を式（7）で与えている.

$$
Q_{E}=0.943 \pi d K_{L} L_{E}^{3 / 4} \Delta T_{E}^{3 / 4}
$$

ここで, $d$ はサーモサイフォンの内径, $K_{L}$ は質量係数, $L_{E}$ は蒸発部長さ, $\Delta T_{E}$ は加熱面過熱度 $\left(=T_{E}-T_{S}\right)$ である. ただし， $K_{L}$ は式（8）で表される.

$$
K_{L}=\left(\frac{\Gamma \rho g \lambda}{v}\right)^{1 / 4}
$$

ここで, $\rho$ は作動液の密度， $g$ は重力加速度， $\lambda$ は作動液の熱伝導率， $v$ は作動液の動粘性係数である.

また, 凝縮部においては, 膜状凝縮の熱伝達理論として Nusselt の液膜理論 ${ }^{(12)}$ を用い, 凝縮部の伝熱量 $Q_{C}$ を 式（9）で与えている.

$$
Q_{C}=0.943 \pi d K_{L} L_{C}^{3 / 4} \Delta T_{C}^{3 / 4}
$$

ここで， $L_{C}$ は凝縮部長さである.

式（7），(9）において，蒸発部と凝縮部の間の断熱部が完全に断熱されていると仮定すると， $Q_{E}=Q_{C}=Q_{F}$ とな る. そして，式（7）を $\Delta T_{E}$ について，式（9）を $\Delta T_{C}$ について解き，それらの和 $\Delta T_{E}+\Delta T_{C}\left(=T_{E}-T_{C}=\Delta T_{E C}\right)$ を求 め, $Q_{F}$ について解くことにより, 膜状凝縮サーモサイフォンの熱輸送量 $Q_{F}$ は式（10）となる.

$$
Q_{F}=0.943 \pi d K_{L}\left(\frac{L_{E} L_{C}}{L_{E}+L_{C}}\right)^{3 / 4} \Delta T_{E C}^{3 / 4}
$$

\section{$3 \cdot 2$ 滴状凝縮サ一モサイフォンのシステム解析理論}

本研究では，滴状凝縮サーモサイフォンの熱輸送特性を理論的に求めるために，式（9）に替えて，式（5）に サーモサイフォン凝縮部の内表面積を乗じて求めた式（11）を用いる.

$$
Q_{C}=\frac{\pi d L_{C}}{n r_{\max }^{1 / n}} \int_{r_{\min }}^{r_{\max }} \frac{r^{(1-n) / n}\left(\frac{\Delta T_{C}}{T_{S}}-\frac{2 \sigma v_{l}}{r \Gamma}\right)}{\frac{K_{1} r}{\lambda T_{S}}+\frac{K_{2}}{q_{2}}} d r
$$

$3 \cdot 1$ 節と同様に，式（7），(11）において，蒸発部と凝縮部の間の断熱部が完全に断熱されていると仮定する と, $Q_{E}=Q_{C}=Q_{D}\left(Q_{D}\right.$ : 滴状凝縮サーモサイフォンの熱輸送量）となる. そして，式（7）を $\Delta T_{E}$ にいて，式（11） を $\Delta T_{C}$ について解き $\left(2 \cdot 2\right.$ 節で示した $n \geqq 1.4$ の関係より, 簡単のため $n=2$ とする. ), それらの和 $\Delta T_{E C}$ は式 (12) となる.

$$
\Delta T_{E C}=A Q_{D}^{4 / 3}+B Q_{D}+C
$$


ここで，式（12）中の $A ， B ， C$ はそれぞれ，式（13）～（15）で表される.

$$
\begin{gathered}
A=\frac{1}{\left(0.943 \pi d K_{L}\right)^{4 / 3} L_{E}} \\
B=\frac{-\sqrt{K_{1} K_{2} T_{S} r_{\max }}}{\pi d L_{C} \sqrt{q_{2} \lambda}\left[\arctan \left(D \sqrt{r_{\min }}\right)-\arctan \left(D \sqrt{r_{\max }}\right)\right]} \\
C=-\frac{2 K_{1} q_{2} v_{l} \sigma}{K_{2} \Gamma \lambda}+\frac{2 v_{l} \sigma \sqrt{K_{1} q_{2} T_{S}}\left(\sqrt{r_{\min }}-\sqrt{r_{\max }}\right)}{\Gamma \sqrt{K_{2} \lambda r_{\min } r_{\max }}\left[\arctan \left(D \sqrt{r_{\min }}\right)-\arctan \left(D \sqrt{r_{\max }}\right)\right]}
\end{gathered}
$$

式（14），(15）中の D は式（16）で表される.

$$
D=\sqrt{\frac{K_{1} q_{2}}{K_{2} T_{S} \lambda}}
$$

式（12）を $Q_{D}$ について解くと, 正の実数解, すなわち滴状凝縮サーモサイフォンの熱輸送量 $Q_{D}$ は式（17）と なる.

$$
\begin{aligned}
Q_{D}= & -\frac{B^{3}}{4 A^{3}}-\frac{1}{2} \sqrt{\frac{B^{6}}{4 A^{6}}-\frac{2 B^{2}\left(C-\Delta T_{E C}\right)}{A^{3}}+E+F} \\
& +\frac{1}{2} \sqrt{\frac{B^{6}}{2 A^{6}}-\frac{4 B^{2}\left(C-\Delta T_{E C}\right)}{A^{3}}-E-F+\frac{B\left[B^{8}-12 A^{3} B^{4}\left(C-\Delta T_{E C}\right)+24 A^{6}\left(C-\Delta T_{E C}\right)^{2}\right]}{4 A^{9} \sqrt{\frac{B^{6}}{4 A^{6}}-\frac{2 B^{2}\left(C-\Delta T_{E C}\right)}{A^{3}}+E+F}}}
\end{aligned}
$$

ここで，式（17）中の $E ， F$ はそれぞれ，式（18），(19）で表される.

$$
\begin{aligned}
& E=\frac{4\left(\frac{2}{3}\right)^{1 / 3}\left(C-\Delta T_{E C}\right)^{3}}{\left\{9 A^{3} B^{2}\left(C-\Delta T_{E C}\right)^{4}+\sqrt{3 A^{6}\left(C-\Delta T_{E C}\right)^{8}\left[27 B^{4}+256 A^{3}\left(-C+\Delta T_{E C}\right)\right]}\right\}^{1 / 3}} \\
& F=\frac{\left\{9 A^{3} B^{2}\left(C-\Delta T_{E C}\right)^{4}+\sqrt{3 A^{6}\left(C-\Delta T_{E C}\right)^{8}\left[27 B^{4}+256 A^{3}\left(-C+\Delta T_{E C}\right)\right]}\right\}^{1 / 3}}{2^{1 / 3} 3^{2 / 3} A^{3}}
\end{aligned}
$$

以下，2，3 章で示した種々の計算式を用い，滴状凝縮サーモサイフォンの熱輸送特性の理論解析，およびサー モサイフォンの熱輸送特性に及ぼす凝縮形態の影響について理論的に検討を行う。なお，式（17）を用いて $Q_{D}$ を求めるに際し，式 (14)，（15）中の $r_{\text {min }}$ は式（6）で与えられるが，式（6）中の $\Delta T_{C}$ は未知の変数である. そ のため，本計算においては，式（11）を $n=2$ として $\Delta T_{C}$ について解いた方程式と式（17）を用いた反復計算（収

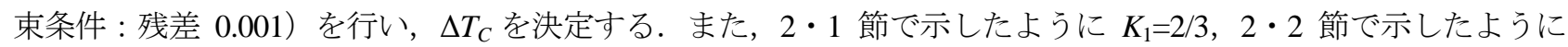
$r_{\max }=1.1 \times 10^{-3} \mathrm{~m}$ とし, また $K_{2}$ については, 表 1 中の滴状凝縮促進剤をオレイン酸とした場合の $K_{2}=2.155$ を用い, 比熱比 $\kappa$, ガス定数 $R$, その他の物性值には水（液体または気体）の值を用いて計算を行う. 


\section{4. 結果および考察}

\section{$4 \cdot 1$ 熱輸送量}

図 2 は, 蒸発部長さ $L_{E}=$ 凝縮部長さ $L_{C}=0.5 \mathrm{~m}$, サーモサイフォン内径 $d=0.03 \mathrm{~m}$ における, サ一モサイフォンの 熱輸送量 $Q$ と熱源温度差 $\Delta T_{E C}$ の関係を飽和蒸気温度 $T_{S}$ をパラメータとして示す．なお，サーモサイフォンの熱 輸送量 $Q$ は，膜状凝縮の場合を式（10）, 滴状凝縮の場合を式（17）より求めている. 図 2 より，いずれの凝縮 形態においても，すべての $T_{S}$ において， $\Delta T_{E C}$ の増加に対し $Q$ の值は増加している. そして, $T_{S}$ の増加に対し $Q$ の值は増加している. また, 凝縮形態の違いについて比較すると, いずれの $T_{S}$ におても, 膜状凝縮よりも滴状 凝縮の場合に大きな $Q$ の值を示している. このことから, サーモサイフォン凝縮部に膜状凝縮に替えて滴状凝縮 を適用することにより，熱輸送量は増加することがわかる.

そこで, 膜状凝縮の熱輸送量 $Q_{F}$ に対寸る滴状凝縮の熱輸送量 $Q_{D}$ の増加割合 $Q^{*}\left(=\left(Q_{D}-Q_{F}\right) / Q_{F}\right)$ を求め, $\Delta T_{E C}$ との関係を $T_{S}$ をパラメータとして図 3 に示す．図中のプロットは $Q^{*}$ 実験值である. 以下, 実験の概略につい て簡単に記す. 実験には, $L_{E}=L_{C}=0.5 \mathrm{~m}, d=0.03 \mathrm{~m}$, 断熱部長さ $0.25 \mathrm{~m}$ の 2 本の銅製サーモサイフォン (作動流体 : 水, 封入率 60\%）を用いた.一方のサーモサイフォン凝縮部にはオレイン酸とエタノールの混合溶液 (混合比 1:20) を満たし，30 分間放置してオレイン酸を凝縮面に吸着させることにより, 滴状凝縮面とした. 他方のサ一モサイ フォン凝縮部は特別な処理を施さず，膜状凝縮面とした． 2 本のサーモサイフォンを同一条件下で同時に作動さ せ, 蒸発部の加熱温度, 凝縮部の冷却水流量を種々に変化させて実験を行った. 実験中のサーモサイフォン内の 飽和蒸気温度 $T_{S}$ は, 実験条件の違いによる変化やばらつきはあるものの平均でおよそ $40^{\circ} \mathrm{C}\left(30 \sim 45^{\circ} \mathrm{C}\right)$ であっ た．なお，実験の詳細，および実験值の算出方法等については文献 ${ }^{(7)}$ に記載されている.

図 3 より, すべての $T_{S}$ において, $\Delta T_{E C}$ の増加に対し $Q^{*}$ の值は増加している. そして, $T_{S}$ の増加に対し $Q^{*}$ の值 は増加している，本計算範囲において，サーモサイフォン凝縮部に膜状凝縮に替えて滴状凝縮を適用することに より，40〜60\%程度の熱輸送量の増加が見られた．また， $T_{S}=40^{\circ} \mathrm{C}$ の理論值と実験值を比較すると，定量的には良 く一致している，定性的傾向には差異が見られるが，実験における $T_{S}$ の変化やばらつきが一因ではないかと考えている.

\section{$4 \cdot 2$ 熱抵抗}

図 4 は, 蒸発部長さ $L_{E}=$ 凝縮部長さ $L_{C}=0.5 \mathrm{~m}$, サーモサイフォン内径 $d=0.03 \mathrm{~m}$ における, サーモサイフォンの 熱抵抗 $R_{H P}$ と熱源温度差 $\Delta T_{E C}$ の関係を飽和蒸気温度 $T_{S}$ をパラメータとして示す．なお，サーモサイフォンの熱 抵抗 $R_{H P}$ は式（20）より求める.

$$
R_{H P}=\frac{\Delta T_{E C}}{Q}
$$

なお， $R_{H P}$ はサーモサイフォンの熱輸送能力の評価に用いる值であり，この值が小さいほど優れた熱輸送能力を示す． 図 4 より, いずれの凝縮形態においても, すべての $T_{S}$ において, $\Delta T_{E C}$ の増加に対し $R_{H P}$ の值は増加している.

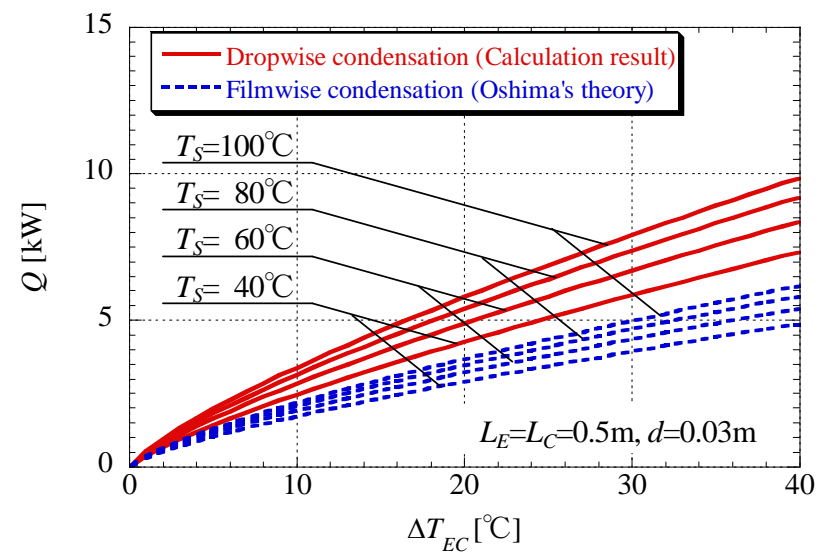

Fig. 2 Relationship between $\Delta T_{E C}$ and $Q$

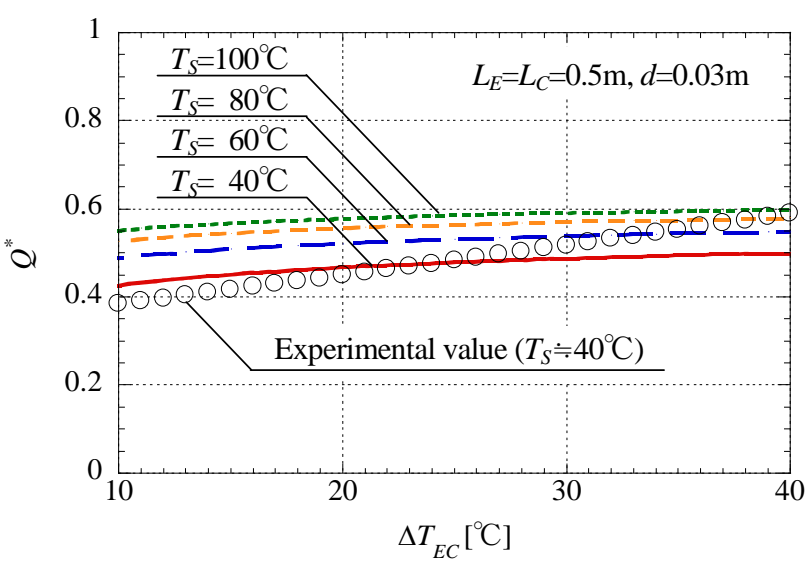

Fig. 3 Relationship between $\Delta T_{E C}$ and $Q^{*}$ 


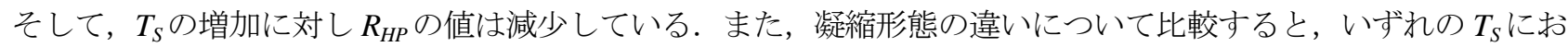
いても, 膜状凝縮よりも滴状凝縮の場合に小さな $R_{H P}$ の值を示している. このことから，サーモサイフォン凝縮 部に膜状凝縮に替えて滴状凝縮を適用することにより, サーモサイフォンの熱輸送能力は促進されることがわかる.

そこで, 膜状凝縮の熱抵抗 $R_{H P, F}$ に対寸る滴状凝縮の熱抵抗 $R_{H P, D}$ の減少割合 $R_{H P}{ }^{*} \quad\left(=\left(R_{H P, F}-R_{H P, D}\right) / R_{H P, F}\right)$ を求 め, $\Delta T_{E C}$ との関係を $T_{S}$ をパラメータとして図 5 に示す. 図中のプロットは $R_{H P}{ }^{*}$ の実験值である. 図 5 より,す心゙ ての $T_{S}$ において, $\Delta T_{E C}$ の増加に対し $R_{H P}{ }^{*}$ の值はわずかに増加している. そして, $T_{S}$ の増加に対し $R_{H P}{ }^{*}$ の值はわずかに 増加している. 本計算範囲において, サ一モサイフォン凝縮部に膜状凝縮に替えて滴状凝縮を適用することにより, 30 40\%程度の熱輸送能力の促進が見られた. また, $T_{S}=40^{\circ} \mathrm{C}$ の理論值と実験值を比較すると, 良好な一致が見られる.

$4 \cdot 1,4 \cdot 2$ 節から, 本計算手法により, 凝縮形態の違いによるサーモサイフォンの熱輸送性能の変化割合を予 測することが可能であると考えられる.

\section{$4 \cdot 3$ サーモサイフォンの熱輸送特性に及ぼす寸法の影響}

本計算手法では, 滴状凝縮の熱伝達理論として用いた Le Fevre-Rose の理論の不完全さや， サーモサイフォン内 の蒸気流が凝縮液挙動に及ぼす影響などが考慮されていないことなどから，絶対的な評価は難しい現状にあるが， 本節では，本計算手法によりサーモサイフォンの熱輸送特性に及ぼす寸法の影響について概略的に検討する.

\section{$4 \cdot 3 \cdot 1$ 蒸発部および凝縮部長さ}

図 6 は, 飽和蒸気温度 $T_{s}=40^{\circ} \mathrm{C}$, サーモサイフォン内径 $d=0.03 \mathrm{~m}$ における, サーモサイフォンの熱流束 $q$ $\left(=Q /\left(\pi d L_{C}\right)\right)$ と熱源温度差 $\Delta T_{E C}$ の関係を蒸発部長さ $L_{E}\left(=\right.$ 凝縮部長さ $\left.L_{C}\right)$ をパラメータとして示す. 図 6 より, いずれの凝縮形態においても， $L_{E}=L_{C}=0.1 \mathrm{~m}$ の場合に最も大きな $q$ の值を示し, $L_{E}=L_{C}$ の増加に対し $q$ の值は減少 している.このことから, 凝縮部長さの増加により, 滴状凝縮サーモサイフォンにおいては, 凝縮面下部になる

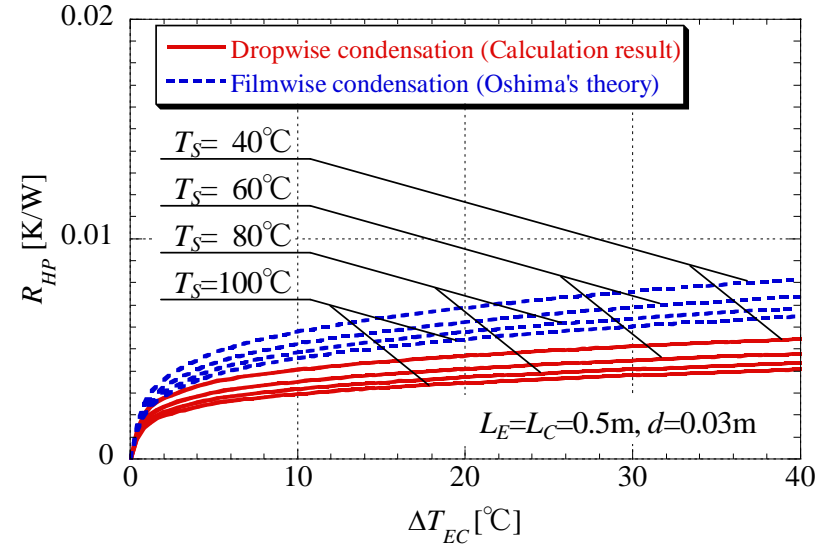

Fig. 4 Relationship between $\Delta T_{E C}$ and $R_{H P}$

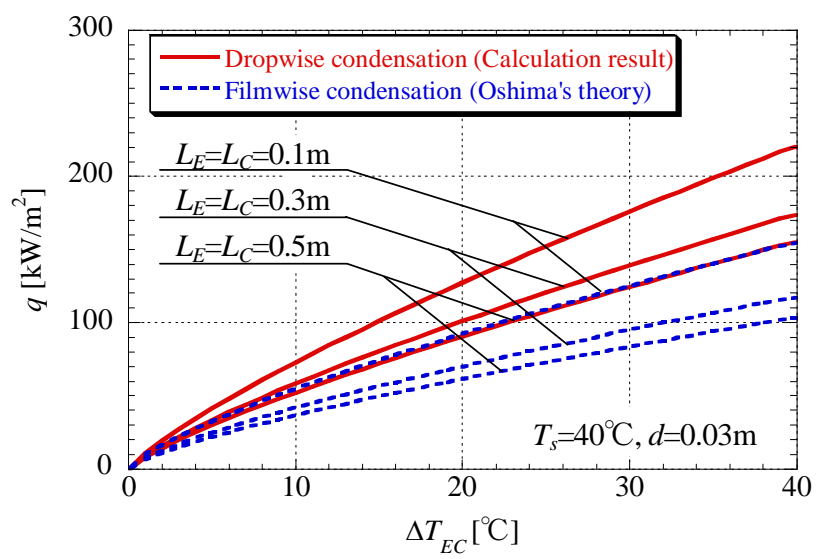

Fig. 6 Relationship between $\Delta T_{E C}$ and $q$ about $L_{E}, L_{C}$

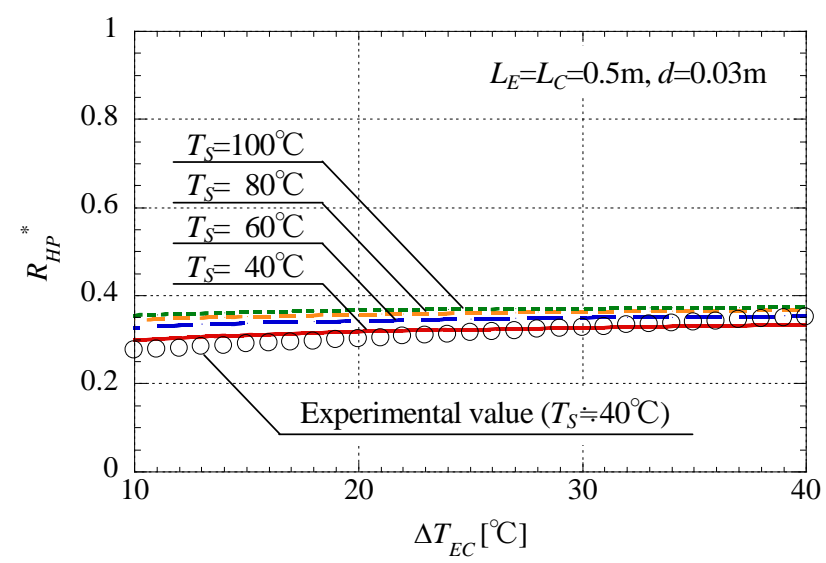

Fig. 5 Relationship between $\Delta T_{E C}$ and $R_{H P}{ }^{*}$

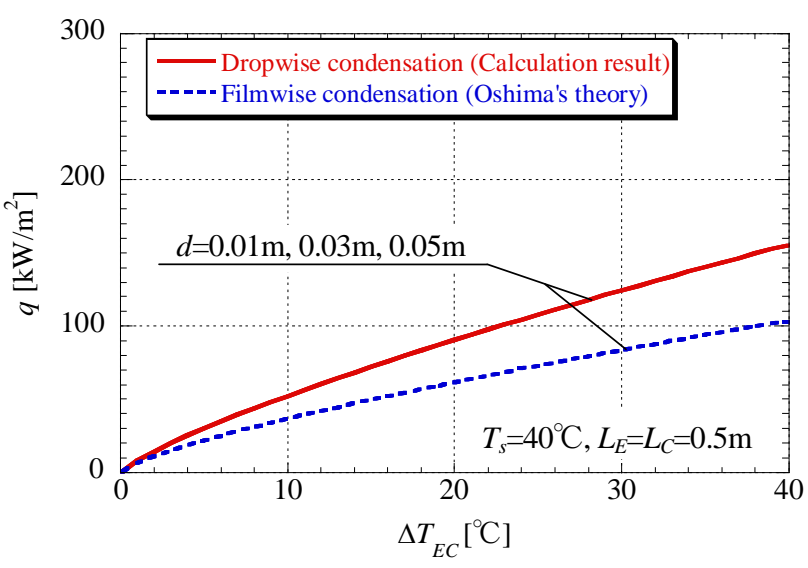

Fig. 7 Relationship between $\Delta T_{E C}$ and $q$ about $d$ 
に伴う液滴の凝縮面被覆率の増大による伝熱阻害が，サーモサイフォンの熱輸送特性に及ぼす影響が顕著になる と考えられる. 同様に，膜状凝縮サーモサイフォンにおいては，凝縮面下部になるに伴う凝縮液膜の増大による 伝熱阻害が，サーモサイフォンの熱輸送特性に及ぼす影響が顕著になると考えられる.

\section{$4 \cdot 3 \cdot 2$ サーモサイフォン内径}

図 7 は, 飽和蒸気温度 $T_{s}=40^{\circ} \mathrm{C}$, 蒸発部長さ $L_{E}=$ 凝縮部長さ $L_{C}=0.5 \mathrm{~m}$ における, サーモサイフォンの熱流束 $q$ と熱源温度差 $\Delta T_{E C}$ の関係をサーモサイフォン内径 $d$ をパラメータとして示す. 図 7 より，いずれの凝縮形態にお いても, $d$ の違いによる $q$ の值への影響は見られない，このことから，サーモサイフォン内径の違いは，滴状凝 縮および膜状凝縮サーモサイフォンの熱輸送特性に影響を及ぼさないと考えられる.

\section{5. 結}

本研究では，滴状凝縮サーモサイフォンの熱輸送特性，および熱輸送特性に及ぼす凝縮形態の影響について， 滴状凝縮の熱伝達理論として Le Fevre-Rose の理論を用い, 膜状凝縮サーモサイフォンのシステム解析理論である 大島の理論と組み合わせることにより，理論的に検討を行った，そして，本研究範囲において以下の結論を得た.

（1）提案した理論的計算手法により, 凝縮形態の違いによるサーモサイフォンの熱輸送性能の変化割合を予 測することが可能であることがわかった.

（2）凝縮部に膜状凝縮に替えて滴状凝縮を適用寸ることにより，40～60\%程度の熱輸送量の増加が見られた.

（3）凝縮部に膜状凝縮に替えて滴状凝縮を適用寸ることにより，30〜40\%程度の熱輸送能力の促進が見られた. 本研究により，滴状凝縮サーモサイフォンの熱輸送特性，および熱輸送特性に及ぼす凝縮形態の影響について， 理論的解析手法の確立の方向性を示寸ことができた. しかし，滴状凝縮の熱伝達理論として用いた Le Fevre-Rose の 理論において, 各種定数の理論的な導出方法が未確立であることなど, さらに精度の高い理論的解析を行うための 今後の課題も存在する.しかしながら, 本研究は, 今後の各種伝熱機器等一の滴状凝縮の応用を考えた場合, 膜状 凝縮を滴状凝縮に変更することによる伝熱促進割合を概算的に評価する簡易手法の確立の一助になると期待される.

\section{文献}

（1）大島耕一, 松下正, 村上正秀, ヒートパイプ工学, (1979), 朝倉書店.

（2）日本ヒートパイプ協会編，実用ヒートパイプ，第2版（2001），日刊工業新聞.

（3）井村英昭, 吉田正道, “二相二重管熱サイホン内の伝熱特性”, 日本機械学会論文集 B 編, Vol. 56, No. 532 (1987), pp. 3816-3820.

（4）植田辰洋，宮下徹，“密閉形二相サーモサイフォンの作動限界について”，日本機械学会論文集 B 編，Vol. 56, No. 526 (1990), pp. 1746-1752.

(5) Shiraiwa, H. and Hosokawa, T., "Fundamental Study on Heat Transfer Characteristics of Two-Phase Closed Thermosyphon in Lower Oscillation（Under Dropwise Condensation in Smaller Input Heat），空気調和・衛生工学会論文集，No. 111 (2006), pp. 19-27.

（6）白岩寛之，細川力，河野行雄，“二相・密閉型サーモサイフォンの低加振時における熱輸送特性に関する基礎的 研究（低熱入力において凝縮部が膜状凝縮の場合）”, 空気調和・衛生工学会論文集, No. 140 (2008), pp. 11-19.

（7）白岩寛之, 細川力, 富田雅史, “二相・密閉型サーモサイフォンの凝縮形態による熱輸送特性”, 空気調和・衛生 工学会論文集, No. 119 (2007), pp. 1-6.

（8） 棚沢一郎，伝熱工学の進展，4 (1976), pp. 288-293.

（9）大島耕一，ヒートパイプ技術，25（1988），pp. 49-77，日本ヒートパイプ協会.

（10）棚沢一郎, 伝熱工学の進展, 4 (1976), p. 292.

（11）細川力, 河合䡒, 藤尾暁彦, 小松源一, “水平円管外面の滴状凝縮熱伝達”, 日本機械学会論文集 B 編, Vol. 51, No. 472 (1985), pp. 4055-4062.

（12）甲藤好郎，伝熱概論，（1964）， pp. 259-277. 